\title{
A ACUMULAÇÃO PRIMITIVA COMO RACIONALIZAÇÃO DOS CORPOS SELVAGENS.
}

\author{
Lilian G. Roizman (Graduanda em Economia no IE/UNICAMP) \\ Eduardo Barros Mariutti (Orientador)
}

\section{Resumo}

A iniciação científica trata-se da do mapeamento da discussão acerca da dimensão da acumulação primitiva que provocou substanciais transformações para a vida das mulheres, seus corpos e seu papel social - feita por Silvia Federici em seu livro "O Calibã e a Bruxa" -, com ênfase no amparo ideológico que esse processo teve na Revolução Científica. A partir da obra de Federici, é possível traçar relações com contribuições de outros autores, de modo a conseguir um entendimento mais profundo sobre o conceito de acumulação primitiva, para além dos marcos estabelecidos por Karl Marx, em O Capital. Com tais interpretações complementares, é possível aproximar os processos de violência contra a mulher, a Natureza e os povos comunitários (seja camponês ou indígena), a partir da matriz comum que têm no pensamento racionalista e individualista burguês, e enquanto componentes de um único processo de acumulação primitiva permanente.

\section{Palavras-chave:}

marxismo, acumulação primitiva, feminismo.

\section{Introdução}

Marx elaborou o conceito de acumulação primitiva no capítulo XXIV de seu livro, no qual descreveu os fundamentos do processo no qual se criam as condições necessárias para o regime capitalista de produção, no que consistiria, em poucas palavras, no processo de separação do produtor dos meios de produção, pelo uso da violência. Com isso, o camponês podia ser transformado em um operário e a terra podia ser concentrada pelos capitalistas enquanto meio de produção. Tal conceito lançou as bases do entendimento de como o capitalismo surge e destrói os modos de produção que o precedem, porém, mostrou-se incompleto em uma série de aspectos, como, por exemplo, suas implicações para as mulheres e sua perpetuação no tempo, até a atualidade.

\section{Resultados e Discussão}

Silvia Federici analisa os impactos desse processo do ponto de vista das mulheres, argumentando que o processo também se caracteriza pela separação das reprodutoras dos meios de reprodução, ou seja, no uso da força para expropriar das mulheres seu controle sobre a reprodução, subordinando-as aos seus maridos pelo uso do salário. Com isso, seria possível a reprodução da força de trabalho também a ritmos industriais, o que não seria possível sem a desvalorização do trabalho doméstico (relacionado ao cuidado com a vida e a casa) e a criação de uma nova racionalidade da sociabilidade dessas mulheres, ou seja, pela domesticação da "mulher selvagem", bruxa.

Com as contribuições de Thompson e Clastres entendemos que a partícula "selvagem" que a acumulação primitiva busca expurgar das mulheres está presente também no modo de vida comunitário, voltado para a subsistência, que aproxima-se do valor de uso, do tempo natural e da mentalidade mítica e religiosa. Tudo que não é voltado para a produção de mercadorias, assim, constituiria um desperdício de tempo, e devendo ser corrigido por meio da disciplina do trabalho ou, no limite, devendo ser eliminado por meio de força.

A necessidade de incorporação ou destruição de tais sociabilidades não capitalistas, radica em muito no próprio pensamento iluminista, que lançou as bases e os valores para a sociedade capitalista que nascia, ao colocar a razão como o princípio de tudo que existe, e atrelá-la, principalmente, aos homens europeus, de acordo com Merchant e Shiva.

\section{Conclusões}

Podemos concluir, assim, que o processo de acumulação primitiva não tem como alvo apenas o camponês, mas também as mulheres; e não trata-se apenas da separação do produtor dos meios de produção, mas também do processo de dissolução de modos de vida que orbitam a produção do comum e do cuidado com a vida. Tais apontamentos seriam relevantes, pois, como aponta Rosa Luxemburgo, o processo de acumulação primitiva é permanente sob o capitalismo, e não pode ser circunscrito a um período histórico restrito. Isso, portanto, nos permitiria uma interpretação mais acurada sobre a história e as estruturas de nossa economia, mas também fenômenos que continuam atuais, como o genocídio indígena, a subestimação das questões ambientais, a violência doméstica, entre muitos outros.

CLASTRES, Pierre. Do Etnocídio, in: Arqueologia da Violência. São Paulo: Editora Cosac \& Naify, 2004.

FEDERICI, Silvia. O Calibã e a Bruxa. São Paulo: Editora Elefante, 2017.

LUXEMBURGO, Rosa. A Acumulação do Capital, sessão III. Rio de Janeiro: Zahar Editores, 1970.

MARX, Karl. O Capital: Crítica da Economia política, capítulos IV e XXIV. São Paulo: Nova Cultural, 1988.

MERCHANT, Carolyn. The Death of Nature: Women, Ecology and the Scientific Revolution. Nova York: Harper \& Row, 1980.

SHIVA, Vandana. Staying Alive: Woman, Ecology and Development, capítulos I e II. Berkeley, California: North Atlantic Books, 2016.

THOMPSON, Edward. Tempo, Disciplina de Trabalho e Capitalismo Indústria in: Costumes em Comum. São Paulo: Cia das Letras, 2005. 